ISSN: 2224-0616

Int. J . Agril. Res. Innov. \& Tech. 3 (1): 78-82, J une, 2013 Available online at http:// www.ijarit.webs.com

\title{
EFFECT OF VARIETY AND LEVEL OF PHOSPHORUS ON THE YIELD AND YIELD COMPONENTS OF LENTIL
}

\author{
S.K. Datta, M.A.R. Sarkar and F.M.J. Uddin* \\ Received 30 April 2013, Revised 6 June 2013, Accepted 20 June 2013, Published online 30 June 2013
}

\begin{abstract}
The experiment was carried out to study the effect of variety and level of phosphorus fertilizer on the yield and yield components of lentil at the Agronomy Field Laboratory, Bangladesh Agricultural University, Mymensingh during October 2009 to March 2010. Three lentil varieties viz. BINA masur 2, BINA masur 3 and BARI masur 4 and four levels of phosphorus viz. $0 \mathrm{kgP} \mathrm{ha}^{-1}\left(\mathrm{P}_{0}\right), 15 \mathrm{~kg} \mathrm{P}^{-1}\left(\mathrm{P}_{15}\right), 30 \mathrm{kgP} \mathrm{ha}^{-1}\left(\mathrm{P}_{30}\right)$ and $45 \mathrm{~kg} \mathrm{P} \mathrm{ha}^{-1}\left(\mathrm{P}_{45}\right)$ were used in this experiment. Varieties showed significant influence on the all characters except plant height. The highest seed yield (1165 kg ha-1) was observed in BARI masur 4, and the lowest seed yield (1028 kg ha-1) was found in BINA masur 3. Phosphorus fertilizer had a significant effect on all the plant characters studied except 1000 seed weight. The highest seed yield $\left(1222 \mathrm{~kg} \mathrm{ha}^{-1}\right)$ was observed in $\mathrm{P}_{45}\left(45 \mathrm{~kg} \mathrm{P} \mathrm{ha}^{-1}\right)$ treatment and the lowest seed yield (893 $\mathrm{kg} \mathrm{ha}^{-1}$ ) was found in $\mathrm{P}_{0}$ treatment. In case of interaction, effect of cultivar and phosphorus fertilizer doses had a significant effect on all the plant characters studied except seeds pod ${ }^{-1}$ and 1000 -seed weight. The highest seed yield (1317 kg ha-1) was obtained in $\mathrm{V}_{3} \mathrm{X}_{45}$ treatment, and the lowest seed yield (830 kg ha-1) was observed in $\mathrm{V}_{2} \mathrm{X} \mathrm{P}_{0}$ treatment combination. Among the varieties BINA masur 2 and BARI masur 4 were superior to BINA masur 3 in respect of yield performance with 30 $\mathrm{kg} \mathrm{P} \mathrm{ha-1}{ }^{-1}$ BARI masur 4 fertilized with $30 \mathrm{~kg} \mathrm{P} \mathrm{ha}^{-1}$ produced the highest seed yield.
\end{abstract}

Keywords: Lentil, Yield, Variety, Phosphorus, Seed

Department of Agronomy, Bangladesh Agricultural University, Mymensingh-2202, Bangladesh

*Corresponding author's email: jamil.bau@gmail.com (F.M.J. Uddin)

\section{Introduction}

Lentil (Lens culinaris L. Medik) is one of the most important pulse crops grown in Bangladesh. It belongs to the sub-family Papilionaceae under the family Leguminosae. In Bangladesh, it is popularly known as masur. The lentil crop covers 33.33 per cent of the total area of pulse in the country (BBS, 2012). Total production of lentil in Bangladesh, during 2010-2011 was 228568 tons from an area of 180574 hectare with an average yield of 1.2657 ton ha-1 (BBS, 2012). It occupies a unique position in the world of agriculture by virtue of its high protein content and capacity of fixing atmospheric nitrogen. In developing countries like Bangladesh, pulse constitutes the major concentrate source of dietary protein. It is considered as poor man's meat as well as cheapest source of protein for under privileged group of people who cannot afford to buy animal protein (Gowda and Kaul, 1982).The protein content of lentil seed is found to vary from 25.70 to 33.40 percent (Singh et al., 1994). The Stover of the plants together with husk popularly known as bhushi is highly protein concentrated feed to cattle, horse, pig and sheep
(Tomar et al., 2000). Lentil being a legume crop can fix atmospheric nitrogen through root nodules by Rhizobium bacteria, which may reduce the pressure of nitrogenous fertilizer application to the crop. It is evident that pulse containing cropping pattern helped to increase the organic matter in the soil (Islam, 1988).

Among different released varieties of lentil BINA masur 2, BINA masur 3, BARI masur 4 are mentionable for their growth performance, yield and quality. BARI masur 4 is a high yielding variety and has insect and disease (rust and stemphylum) resistance power. BARI masur 4 was released by the National Seed Board in 1996 for cultivation in Rabi season in Bangladesh. BINA masur 2 and BINA masur 3 are the superior mutant varieties released by the National Seed Board in 2005 for cultivation in Rabi season in Bangladesh. Phosphorus is one of the most important plant nutrient used in crops. It increases the hardness of crop. It also increases the growth and yield of crops. In pulse crop, phosphorus fertilizer has a significant effect on crop yield as it enhances nodulation, which helps to fix more nitrogen from air through their nodules. In Bangladesh, the low yield of lentil may be 
attributed to many reasons such as lack of quality optimum seed rate, using local varieties as planting material, appropriate time of sowing, lack of judicious fertilizer application and specially decrease of organic matter in the soil. Moreover, the different doses of phosphorus will help to determine the suitable dose, thereby reducing the misuse of phosphorus fertilizer. In view of above discussion, the present study was undertaken to find out the effect of variety and level of phosphorus fertilizer on the yield and yield components of lentil.

\section{Materials and Methods}

The experiment was conducted at the Agronomy Field Laboratory, Bangladesh Agricultural University, Mymensingh during October 2009 to March 2010 to study the effect of variety and level of phosphorus on the yield and yield components of lentil. The land is medium high having sandy loam texture soil and belongs to Sonatala series under non-calcareous dark gray flood plain soil type with soil pH 6.7 (UNDP and FAO, 1998). The soil is low in organic matter content and its general fertility level is low. Status of phosphorus and nitrogen and cation exchange capacity is medium and that of potassium is low (BARC, 1999). The experiment was laid out in a randomized complete block design with three replications. The total numbers of plots were 36 . The unit plot size was $4.0 \mathrm{~m}$ x $2.5 \mathrm{~m}$. Replication to replication and plot to plot distances were 1.0 $\mathrm{m}$ and $0.5 \mathrm{~m}$, respectively. The experimental land was first opened on 26 October 2009 with a power tiller. Later on, the land was ploughed and cross-ploughed two times by country plough followed by laddering to obtain the desirable tilth. The corners of the plot were spaded and larger clods were broken into pieces by wooden hammer. All the weeds and stubble were removed and the land was laid out as per the experimental design. Different doses of $\mathrm{P}$ were used in different plots. Fertilizers were applied at the rate of 50, 40 and $10 \mathrm{~kg} \mathrm{ha}^{-1}$ Urea, Muriate of potash (MOP) and Zinc sulphate ( $\mathrm{ZnSO} 4)$, respectively at final land preparation. P was applied in the term of TSP (Triple super phosphate) as per treatment specification at final land preparation. Seeds with $92 \%$ germination capacity were sown in line continuously having line to line distance $30 \mathrm{~cm}$ on 18 November 2009 at the rate of $40 \mathrm{~kg} \mathrm{ha}^{-1}$.

The crop was grown under rainfed condition. The foot and root rot disease was controlled by spraying of Propiconazol $250 \mathrm{EC}$ @ $20 \mathrm{ml}$ per 5 decimal lands. Weeds were controlled by two hand weeding with niri. The first weeding was done on 8 December and second weeding was done on 29 December 2009. The crop was harvested at full maturity on 8 March 2010.The harvested crop was brought to the threshing floor and dried for three days. Then the seed and straw were separated and cleaned. The cleaned seeds were dried in sun for 3-4 consecutive days. The yield of seed was adjusted at $10 \%$ moisture level.

Data on crop characters were recorded at harvest. The yield contributing characters were recorded from 5 randomly selected plants in each plot and their mean values were determined. The yields were taken plot-wise by harvesting central $10 \mathrm{~m}^{2}$ area of each plot and then it was converted to hectare basis. Data were collected on the following parameters: Plant height $(\mathrm{cm})$, Number of nodules plant ${ }^{-1}$ (Data recorded at 60 DAS), Number of pods plant-1, Number of seeds pod ${ }^{-1}$, Number of seeds plant-1, Seed yield (kg ha-1).

The collected data were analyzed statistically using the analysis of variance technique with the help of computer package MSTAT and mean differences were adjudged by Duncan's Multiple Ranged Test (DMRT) (Gomez and Gomez, 1984).

\section{Results and Discussion}

Varieties showed significant influence on all parameters except plant height. The variety BINA masur 2 gave the highest plant height $(38.18 \mathrm{~cm})$, number of nodules plant ${ }^{-1}(17.36)$, number of pods plant ${ }^{-1}$ (128.5) and the cultivar BARI masur 4 produced the lowest plant height( $36.92 \mathrm{~cm})$, number of nodules plant -1 (14.72), number of pods plant ${ }^{-1}$ (111.70), (Table 1). BINA masur 3 produced the highest number of seeds pod ${ }^{-1}(1.68)$ and the lowest number of seeds pod-1 (1.58) was observed from the cultivar BARI masur 4 . BINA masur 2 was intermediate in this respect. The cultivar BARI masur 4 produced the highest weight of 1,000 seed $(18.77 \mathrm{~g})$ and the lowest weight of 1000 seed (16.42 g) was observed from the cultivar BINA masur 2. The highest seed yield (1165 kg ha-1) was recorded from cultivar BARI masur 4 which was statistically identical with BINA masur 2 (1133 $\mathrm{kg} \mathrm{ha}^{-1}$ ) and the lowest seed yield (1028 kg ha-1) was found in the cultivar BINA masur 3 (Table 1). The cultivar BINA masur 3, BARI masur 4 and BINA masur 2 showed significant influence on all parameters except 1000-seed weight and harvest index. BARI masur 4 gave the highest (26.74\%) harvest index and the lowest (25.62\%) was found in BINA masur 2. The highest seed yield (0.63 t ha-1) and straw yield (1.73 t ha1) were obtained from BARI masur 3 (Wasiq, 2006). 
Table 1. Effect of varieties on the yield and yield components of lentil

\begin{tabular}{lcccccc}
\hline Varieties & $\begin{array}{c}\text { Plant } \\
\text { height at } \\
\text { harvest } \\
(\mathrm{cm})\end{array}$ & $\begin{array}{c}\text { Nodules } \\
\text { plant-1 } \\
(\text { no. })\end{array}$ & $\begin{array}{c}\text { Number of } \\
\text { pods plant-1 }\end{array}$ & $\begin{array}{c}\text { Seeds pod }-1 \\
(\text { no. })\end{array}$ & $\begin{array}{c}1000 \text {-seed } \\
\text { weight (g) }\end{array}$ & $\begin{array}{c}\text { Seed yield } \\
\left(\mathrm{kg} \mathrm{ha}^{-1}\right)\end{array}$ \\
\hline BINA masur 2 $\left(\mathrm{V}_{1}\right)$ & 38.18 & $17.36 \mathrm{a}$ & $128.5 \mathrm{a}$ & $1.64 \mathrm{a}$ & $16.42 \mathrm{~b}$ & $1133 \mathrm{a}$ \\
BINA masur 3 $\left(\mathrm{V}_{2}\right)$ & 37.17 & $15.33 \mathrm{~b}$ & $117.7 \mathrm{~b}$ & $1.68 \mathrm{a}$ & $16.44 \mathrm{~b}$ & $1028 \mathrm{~b}$ \\
BARI masur 4 $\left(\mathrm{V}_{3}\right)$ & 36.92 & $14.72 \mathrm{~b}$ & $111.7 \mathrm{c}$ & $1.58 \mathrm{~b}$ & $18.77 \mathrm{a}$ & $1165 \mathrm{a}$ \\
F-test & $\mathrm{NS}$ & $* *$ & $* *$ & $* *$ & $* *$ & $* *$ \\
CV $(\%)$ & 5.65 & 8.45 & 5.19 & 4.41 & 4.73 & 4.58 \\
\hline
\end{tabular}

In a column, figure with same letter dot not differ significantly at $\mathrm{P} \leq 0.05 ;{ }^{* *}$ Significant at $1 \%$ level of probability; NS = Not significant; Nodulation data were recorded at 60 DAS.

Phosphorus fertilizer had a significant effect on all the plant characters studied except 1000- seed weight. The highest plant height $(39.32 \mathrm{~cm})$ was observed in $\mathrm{P}_{45}$, which was statistically identical with $\mathrm{P}_{30}$ and followed by $\mathrm{P}_{15}$ and $\mathrm{P}_{0}$ treatment. The highest number of nodules plant ${ }^{-1}$ (18.55) was observed in $\mathrm{P}_{45}$ treatment, which was statistically identical with $\mathrm{P}_{30}$ treatment (18.41) and the lowest nodules (11.81), was observed in $\mathrm{P}_{0}$ treatment. The highest pods plant $^{-1}$ (127.80) was observed in $\mathrm{P}_{45}$ treatment, which was statistically identical with $\mathrm{P}_{30}$ treatment (18.41) and the lowest pods plant ${ }^{-1}$ (106.5) was observed in $\mathrm{P}_{0}$ treatment. The highest seeds pod-1 (1.707) was observed in $\mathrm{P}_{45}$ treatment, which was statistically identical with in $\mathrm{P}_{30}$ treatment (1.700) and the lowest seeds pod-1 (1.523) was observed in $\mathrm{P}_{0}$ treatment. Seeds pod-1 were increased with the increased level of phosphorus fertilizers as reported by Zeidan (2007). The highest 1000-seed weight (17.39 g) was observed in $\mathrm{P}_{30}$ treatment and the lowest 1000 -seed weight $(16.84 \mathrm{~g})$ was observed in $\mathrm{P}_{0}$ treatment. The highest seed yield (1222 kg ha-1) was observed in $\mathrm{P}_{45}$ treatment, which was statistically identical with $\mathrm{P}_{30}$ treatment (1211 kg ha-1) and the lowest seed yield (893 kg ha-1) was observed in $\mathrm{P}_{0}$ treatment (Table 2). The application of 20, 40 and $60 \mathrm{~kg} \mathrm{P}_{2} \mathrm{O}_{5}$ $\mathrm{ha}^{-1}$ at the vegetative stage and again at either $50 \%$ flowering or $50 \%$ pod formation, maximum seed yield (2.68 ton ha-1) was obtained with the application of $60 \mathrm{~kg} \mathrm{P}_{2} \mathrm{O}_{5}$ ha1. The optimum $P$ rate was calculated to be 56 $\mathrm{kg} \mathrm{ha}^{-1}$ (Siag et al., 1990). The response of 4 levels of $\mathrm{P}$ viz. $0,20,40$ and $60 \mathrm{~kg} \mathrm{P}_{2} \mathrm{O}_{5}$ ha $^{-1}$ on grain yield of lentil showed that the grain yield of lentil increased significantly at all levels of $P$ application over control. The response of $\mathrm{P}$ application over control increased content of soil P (Azad et al., 1991). According to Zafar et al. (2003) maximal does of phosphorus $75 \mathrm{~kg}$ $\mathrm{P}_{2} \mathrm{O}_{5}$ ha $^{-1}$ has proved a significant dose for getting a good seed yield of lentil (1250 kg ha-1). Barua et al. (2011) reported that cultivation of lentil using $85 \mathrm{~kg} \mathrm{P}$ ha-1 $^{-1}$ with compost resulted best seed yield. Application of phosphorus 50 $\mathrm{kg} \mathrm{ha}^{-1}$ may be considered as optimum dose for higher yield of lentil (Mahmood et al., 2010).

Table 2. Effect of level of phosphorus on the yield and yield components of lentil

\begin{tabular}{|c|c|c|c|c|c|c|}
\hline $\begin{array}{l}\text { Phosphorus } \\
\text { levels } \\
\left(\mathrm{kg} \mathrm{ha}^{-1}\right)\end{array}$ & $\begin{array}{l}\text { Plant height } \\
\text { at harvest } \\
(\mathrm{cm})\end{array}$ & $\begin{array}{c}\text { Nodules } \\
\text { plant-1 } \\
\text { (no.) }\end{array}$ & $\begin{array}{l}\text { pods plant } \\
\text { (no.) }\end{array}$ & $\begin{array}{c}\text { Seeds } \\
\operatorname{pod}^{-1} \text { (no.) }\end{array}$ & $\begin{array}{l}\text { 1000-seed } \\
\text { weight (g) }\end{array}$ & $\begin{array}{c}\text { Seed yield } \\
\left(\mathrm{kg} \mathrm{ha}^{-1}\right)\end{array}$ \\
\hline $\mathrm{P}_{0}$ & $34.46 \mathrm{c}$ & $11.81 \mathrm{c}$ & $106.5 \mathrm{c}$ & $1.523 \mathrm{c}$ & 16.84 & $893 \mathrm{c}$ \\
\hline $\mathrm{P}_{15}$ & $36.96 \mathrm{~b}$ & $14.44 \mathrm{~b}$ & $115.9 \mathrm{~b}$ & $1.613 \mathrm{~b}$ & 17.25 & $1108 \mathrm{~b}$ \\
\hline $\mathrm{P}_{30}$ & $38.94 \mathrm{ab}$ & $18.41 \mathrm{a}$ & $126.9 \mathrm{a}$ & $1.700 \mathrm{a}$ & 17.39 & $1211 \mathrm{a}$ \\
\hline $\mathrm{P}_{45}$ & $39.32 \mathrm{a}$ & $18.55 \mathrm{a}$ & $127.8 \mathrm{a}$ & $1.707 \mathrm{a}$ & 17.35 & $1222 \mathrm{a}$ \\
\hline F-test & $* *$ & $* *$ & ** & $* *$ & NS & $* *$ \\
\hline CV (\%) & 5.65 & 8.45 & 5.19 & 4.41 & 4.73 & 4.58 \\
\hline
\end{tabular}

In a column, figure with same letter dot not differ significantly at $\mathrm{P} \leq 0.05 ;$ ** Significant at $1 \%$ level of probability; NS = Not significant; Nodulation data were recorded at 60 DAS.

In case of interaction effect of cultivar and phosphorus, all the plant characters significantly affected except seeds pod ${ }^{-1}$ and 1000-seed weight. The highest plant height $(40.03 \mathrm{~cm})$ was obtained in $\mathrm{V}_{1} \mathrm{X}_{30}$ treatment combination and the lowest plant height $(33.70 \mathrm{~cm})$ was obtained in $\mathrm{V}_{3} \mathrm{X} \mathrm{P}_{0}$ treatment combination. The highest nodules plant ${ }^{-1}$ (20.44) was observed in $\mathrm{V}_{1} \mathrm{X}_{30}$ treatment combination and the lowest nodules plant ${ }^{-1}$ 
(12.22) was observed in $\mathrm{V}_{3} \mathrm{X} \mathrm{P}_{0}$ treatment combination. The highest pods plant-1 (137.0) was observed in $\mathrm{V}_{1} \mathrm{X} \mathrm{P}_{0}$ treatment combination and the lowest pods plant-1 (97.60) was observed in $\mathrm{V}_{3} \times \mathrm{P}_{0}$ treatment combination. The highest seeds pod-1 (1.73) was observed in $\mathrm{V}_{2} \mathrm{X} \mathrm{P}_{30}$ and $\mathrm{V}_{2} \mathrm{X} \mathrm{P}_{45}$ and the lowest seeds pod-1 (1.47) was observed in $\mathrm{V}_{3} \mathrm{X} \mathrm{P}_{0}$ treatment combination. The highest 1000-seed weight $(19.01 \mathrm{~g})$ was observed in $\mathrm{V}_{3} \mathrm{X}_{30}$ treatment combination and the lowest 1000-seed weight
(16.10 g) was observed in $\mathrm{V}_{2} \mathrm{X} \mathrm{P}_{0}$ treatment combination. The highest seed yield (1317 kg

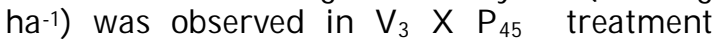
combination, which was statistically identical with (1280 kg ha-1) and (1250 kg ha-1) in $\mathrm{V}_{3} \times \mathrm{P}_{30}$ and $\mathrm{V}_{1} \mathrm{X} \quad \mathrm{P}_{30}$ treatment combination, respectively and the lowest seed yield (830 kg ha-1) was observed in $\mathrm{V}_{2} \mathrm{X} \mathrm{P}_{0}$ treatment combination.

Table 3. Interaction effect of variety and level of phosphorus on the yield and yield components of lentil

\begin{tabular}{lcccccc}
\hline Interaction & $\begin{array}{c}\text { Plant height } \\
(\mathrm{cm})\end{array}$ & $\begin{array}{c}\text { Nodules } \\
\text { plant }^{-1}(\text { no.) })\end{array}$ & $\begin{array}{c}\text { Total pods } \\
\text { plant }^{-1} \\
(\text { no. })\end{array}$ & $\begin{array}{c}\text { Seeds pod-1 } \\
(\text { no. })\end{array}$ & $\begin{array}{c}\text { 1000-seed } \\
\text { weight (g) }\end{array}$ & $\begin{array}{c}\text { Seed yield } \\
\left(\mathrm{kg} \mathrm{ha}^{-1}\right)\end{array}$ \\
\hline $\mathrm{V}_{1} \times \mathrm{P}_{0}$ & $35.54 \mathrm{bc}$ & $12.67 \mathrm{de}$ & $116.7 \mathrm{c}$ & 1.50 & 16.21 & $940 \mathrm{f}$ \\
$\mathrm{V}_{1} \times \mathrm{P}_{15}$ & $37.37 \mathrm{abc}$ & $16.00 \mathrm{bc}$ & $125.6 \mathrm{bc}$ & 1.67 & 16.42 & $1140 \mathrm{~cd}$ \\
$\mathrm{~V}_{1} \times \mathrm{P}_{30}$ & $40.03 \mathrm{a}$ & $20.44 \mathrm{a}$ & $137.0 \mathrm{a}$ & 1.70 & 16.50 & $1250 \mathrm{ab}$ \\
$\mathrm{V}_{1} \times \mathrm{P}_{45}$ & $39.77 \mathrm{a}$ & $20.33 \mathrm{a}$ & $134.7 \mathrm{a}$ & 1.71 & 16.53 & $1200 \mathrm{bc}$ \\
$\mathrm{V}_{2} \times \mathrm{P}_{0}$ & $34.13 \mathrm{c}$ & $11.55 \mathrm{e}$ & $105.3 \mathrm{~d}$ & 1.60 & 16.10 & $830 \mathrm{~g}$ \\
$\mathrm{~V}_{2} \times \mathrm{P}_{15}$ & $37.30 \mathrm{abc}$ & $14.33 \mathrm{~cd}$ & $117.9 \mathrm{c}$ & 1.67 & 16.44 & $1033 \mathrm{e}$ \\
$\mathrm{V}_{2} \times \mathrm{P}_{30}$ & $38.43 \mathrm{ab}$ & $18.11 \mathrm{ab}$ & $122.7 \mathrm{c}$ & 1.73 & 16.67 & $1100 \mathrm{de}$ \\
$\mathrm{V}_{2} \times \mathrm{P}_{45}$ & $38.80 \mathrm{ab}$ & $17.33 \mathrm{~b}$ & $124.8 \mathrm{bc}$ & 1.73 & 16.54 & $1150 \mathrm{~cd}$ \\
$\mathrm{~V}_{3} \times \mathrm{P}_{0}$ & $33.70 \mathrm{c}$ & $11.22 \mathrm{e}$ & $97.60 \mathrm{~d}$ & 1.47 & 18.20 & $910 \mathrm{fg}$ \\
$\mathrm{V}_{3} \times \mathrm{P}_{15}$ & $36.20 \mathrm{abc}$ & $13.00 \mathrm{de}$ & $104.3 \mathrm{~d}$ & 1.50 & 18.90 & $1150 \mathrm{~cd}$ \\
$\mathrm{~V}_{3} \times \mathrm{P}_{30}$ & $38.37 \mathrm{ab}$ & $16.67 \mathrm{bc}$ & $121.0 \mathrm{c}$ & 1.67 & 19.01 & $1283 \mathrm{ab}$ \\
$\mathrm{V}_{3} \times \mathrm{P}_{45}$ & $39.40 \mathrm{ab}$ & $18.00 \mathrm{ab}$ & $124.0 \mathrm{bc}$ & 1.68 & 18.98 & $1317 \mathrm{a}$ \\
$\mathrm{F}-$ test & $*$ & $*$ & $*$ & NS & $\mathrm{NS}$ & $*$ \\
$\mathrm{CV}(\%)$ & 5.65 & 8.45 & 5.19 & 4.41 & 4.73 & 4.58 \\
\hline
\end{tabular}

In a column, figure with same letter dot not differ significantly at P $\leq 0.05$; * Significant at $5 \%$ level of probability; NS = Not significant; Nodulation data were recorded at 60 DAS.

Based on the experimental results, it may be concluded that $30 \mathrm{~kg} \mathrm{P}$ ha $^{-1}$ is the best for maximizing seed yield in lentil and among the varieties BINA masur 2 and BARI masur 4 were found superior to BINA masur 3 in respect of seed yield. BARI masur 4 can be grown with $30 \mathrm{~kg} \mathrm{P} \mathrm{ha}^{-1}$ to obtain the highest seed yield.

\section{References}

Azad, A.S., Gill, A.S. and Dhaliwal, H.S. 1991. Response of phosphorus and Rhizobium culture on grain yield of lentil. Lens Newsletter. 18 (1-2): 14: 14-19.

BARC (Bangladesh Agricultural Research Council). 1999. Fertilizer Recommendation Guide-1999. Bangladesh Agricultural Research Council, Farmgate, New Airport Road, Dhaka. pp. 30-178.

Barua, R., Bhuiya, M.S.U., Kabir. M.M., Maniruzzaman, S. and Ahmed, Z. 2011. Effect of Mimosa (Mimosa invisia) compost and phosphorus on the yield and yield components of Lentil (Lens culinaris L.). The Agriculturists. 9 (1-2): 63-72.

BBS (Bangladesh Bureau of Statistics). 2012. Statistical Year Book of Bangladesh. Bangladesh Bur. Stat., Stat. Div., Min. Plan. Govt. People's Repub. Bangladesh.

Gomez, K.A. and Gomez, A.A. 1984. Statistical Procedures for Agric. Res. 2nd Edn. J ohn Willey and Sons. New York. pp. 207-215.

Gowda, C.L.L. and Kaul, A.K. 1982. Pulses in Bangladesh, BARI publication. 6 (1): 27-29.

Islam, M.S. 1988. Nutrient status of Bangladesh soils. Annual report for 1988. Bangladesh Agril. Res. Inst., Gazipur, Bangladesh. pp. 82-85.

Mahmood, I., Razzaq, A., Bukhari, S.A.H. and Naveed, T.M. 2010. Optimization of Lentil (Lens culinaris Medic.) cultivars response to NPK under rainfed conditions. J. Agric. Res. 48 (3): 343-351.

Siag, R.K., Verma, B.L. and Sindhu, B. 1990. Effect of irrigation requires and phosphorus 
levels on yield and water use efficiency of chickpea. Indian J. Pulses Res. 3 (1): 31-35.

Singh, G., Mehta, R.H. and Singh, O.P. 1994. Effect of seed rate and method of sowing of lentil. Indian J. Pulses Res. 7 (2): 132-136.

Tomar, S.K., Tripathi, P. and Rajput, A.L. 2000. Effect of genotype, seeding method and diammonium phosphate on yield and protein and nutrient uptake of lentil (Lens culinaris L. Medik). Indian J. Agron. 45 (1): 148-152.

UNDP (United Nations Development Programme) and FAO (Food and Agricultural Organization). 1998. Land Resources Appraisal of Bangladesh for Agric. Development. Report No. 2. Agro-Ecological Regions of Bangladesh. U. N. Dev. Prog. and Food and Agric. Org. pp. 212-221.
Wasiq, I. 2006. Effect of plant density and cultivar on the performance of lentil. M.S. Thesis, Department of Agronomy, Bangladesh Agricultural Universiy, Mymensingh. pp. 39-41.

Zafar, M., Maqsood, M., Rahman, A.M. and Zahid, A. 2003. Growth and yield of lentil as affected by phosphorus . Int. J . Agric. Biol. 5 (1): 98-100.

Zeidan, M.S. 2007. Effect of organic manure and phosphorus fertilizers on growth, yield and quality of lentil plants in sandy soils. Res.J . Agric. Biol. 38 (6-7): 745-752. 